\title{
Effect of Low-Temperature Plasma Nitriding on Corrosion and Surface Properties of Duplex Stainless Steel UNS S32205
}

\author{
Yamid E. Núñez de la Rosa, Oriana Palma Calabokis, Paulo César Borges, and Vladimir Ballesteros Ballesteros
}

\author{
(Submitted October 28, 2019; in revised form March 12, 2020; published online April 6, 2020)
}

\begin{abstract}
The duplex stainless steel UNS S32205 was plasma nitrided at $380{ }^{\circ} \mathrm{C}$ for $10 \mathrm{~h}$ using a gas mixture of $25 \%$ $\mathrm{N}_{2}-75 \% \mathrm{H}_{2}$. The thickness of the nitrided layer was $4.5 \pm 0.5 \mu \mathrm{m}$, composed mainly of nitrogen-expanded austenite and iron nitrides precipitates. There was an increase in surface hardness around 2.6 and 3.8 times in the nitrided layer formed on the austenite and the ferrite phases, respectively, in relation to the untreated samples. The surface texture parameters skewness $\left(S_{\text {sk }}\right)$, maximum peak height $\left(S_{\mathrm{p}}\right)$ and texture aspect ratio $\left(S_{\text {tr }}\right)$ were the most appropriate parameters for studying the topography changes after treatment. An improvement in the localized corrosion properties after the nitriding treatment was revealed by the cyclic polarization curves. The nitrided samples showed higher pitting corrosion and repassivation potentials compared to the untreated material. The ferritic phases and grain boundaries were more susceptible to corrosion in the nitrided samples. The potentiodynamic curves of the nitrided samples exhibited a hillside on the passive-to-transpassive transition. This feature was already observed by other researchers, but it has not been well investigated. Potentiostatic studies demonstrated that metastable pitting took place on this transition.
\end{abstract}

$\begin{array}{ll}\text { Keywords } & \begin{array}{l}\text { corrosion, low-temperature plasma nitriding, } \\ \text { metastable pitting, UNS S32205 }\end{array}\end{array}$

\section{Introduction}

Duplex stainless steels (DSSs) have a two-phase microstructure with equivalent amounts of ferritic $(\alpha)$ and austenitic $(\gamma)$ phases. They are widely used in high-performance components for petrochemical, oil and gas, chemical and nuclear industries because of their superior strength and corrosion resistance, compared to the analogous austenitic steels. However, for some wear-resistant demanding applications, the bulk hardness is not enough to ensure the required performance (Ref 1-7).

Plasma nitriding is a thermochemical surface treatment expected to improve wear properties on duplex stainless steel (DSS) without decreasing the corrosion resistance. When this treatment is carried out at low temperatures $\left(350-420{ }^{\circ} \mathrm{C}\right)$, it is possible to form a layer with higher hardness and better wear properties than the steel substrate (Ref 1-7). The nitrided layer formed at low temperatures is mainly composed by nitrogenexpanded phases without nitrides (Ref 8, 9). The chromium nitrides are formed when the treatment is carried out at higher temperatures $\left(>420^{\circ} \mathrm{C}\right)$. Those precipitates affect the corrosion performance because they create chromium-depleted

Yamid E. Núñez de la Rosa, Oriana Palma Calabokis, and Paulo César Borges, Universidade Tecnológica Federal do Paraná, Curitiba, Brazil; and Vladimir Ballesteros Ballesteros, Facultad de Ingeniería y Ciencias Básicas, Fundación Universitaria Los Libertadores, Bogotá D.C., Colombia. Contact e-mail: yamid@alunos.utfpr.edu.br. regions which hinder the formation of the passive layer (Ref 5-7, 9-12).

Electrochemical techniques, such as electrochemical impedance spectroscopy and potentiodynamic polarization, are commonly used for corrosion studies. The current response is plotted as a function of the potential, when the metal is subjected to the potentiodynamic polarization. Some studies regarding plasma-nitrided DSS have reported polarization curves with a hillside on the passive-to-transpassive transition (Ref 2, 3, 13-17). This hillside was recognized in all cases by a continuous increase followed by a drop in current density at the end of the passivation region. This phenomenon, which has also been reported in the literature, has not been well explained, but it is believed that it is related to the partial rupture of the passive layer followed by its repassivation before the definitive rupture in the transpassive region.

Duplex stainless steels are susceptible to pitting corrosion in many chloride environments (Ref 18-21). Typical currentpotential curves obtained by potentiodynamic polarization have a sudden current increase when the pitting potential $\left(E_{\mathrm{p}}\right)$ or breakdown potential is reached. This marks the passive-totranspassive transition where localized corrosion and transpassive reactions could occur. However, it was demonstrated that pitting nucleation can occur at potentials far below the pitting potential, known as metastable pitting (Ref 22-25). Concerning DSS, metastable signals were evidenced in untreated UNS S32205 and UNS S32750 on the studies performed by Tang et al. and Garfias-Mesias and Sykes, respectively (Ref 26, 27). However, to our knowledge, metastable pitting has not been studied before in plasma-nitrided stainless steels despite the actual importance of these treated alloys.

In the present study, low-temperature plasma-nitrided UNS S32205 was characterized in terms of microstructure, hardness, surface roughness and corrosion behavior. Especially, this study 
emphasized the study of the current density hillside observed at the end of the passivation region.

\section{Materials and Methods}

\subsection{Specimen Preparation}

The stainless steel UNS S32205 was used as the substrate material. Table 1 presents the chemical composition of this material analyzed by mass spectroscopy.

The samples were cut by electro-erosion from a hot-rolled bar (diameter: $85.5 \mathrm{~mm}$ ) up to the dimensions of $(7 \times 20 \times 60) \mathrm{mm}^{3}$. Afterward, they were rectified to remove irregularities and grounded until 600 grit using $\mathrm{SiC}$ grinding papers. Finally, they were ultrasonically cleaned in acetone and dried under hot air.

\subsection{Plasma Nitriding}

Plasma nitriding treatments were carried out in a pulsed plasma reactor with a cold-wall chamber, located at the LabPlasma (UTFPR-Brazil). Prior to plasma treatment and in order to remove the surface oxide layer, sputter cleaning was done using a gas mixture of hydrogen and argon $\left(75 \% \mathrm{H}_{2}\right.$ and $25 \% \mathrm{Ar}, 200 \mathrm{SCCM}$ flux $)$ at a pressure of 3 Torr $(\sim 400 \mathrm{~Pa})$, a voltage of $600 \mathrm{~V}$ and a temperature of $300{ }^{\circ} \mathrm{C}$ for $20 \mathrm{~min}$. The samples were arranged side by side to avoid border effect during plasma nitriding, and they were placed on the sample holder, which behaves as a cathode with respect to the chamber wall. The heating process was controlled by increasing the time that the pulse source was on and off, step by step until the set treatment temperature was achieved and stabilized for $10 \mathrm{~min}$. During this time, the flux of argon was substituted for nitrogen $\left(25 \%\right.$ of $\left.\mathrm{N}_{2}\right)$. The samples were then treated under the constant temperature, pressure, flux and voltage used during sputtering, for $10 \mathrm{~h}$. After this process, the bias voltage and nitrogen flux decreased to zero and the specimens were cooled down to room temperature in a hydrogen gas atmosphere to avoid oxidation during cooling.

\subsection{Characterization: Morphology and Hardness}

The nitrided samples were cross-sectioned, compression mounted in bakelite and polished to a mirror finishing with successive $\mathrm{SiC}$ grinding papers and diamond paste. For revealing microstructure, they were electrochemically etched with a solution of oxalic acid $\left(10 \mathrm{w} / \mathrm{v} \% \mathrm{C}_{2} \mathrm{H}_{2} \mathrm{O}_{4}\right)$ at $4.6 \mathrm{~V}$ for $10 \mathrm{~s}$. Afterward, the microstructure of the nitrided layer was analyzed by light optical microscope (OM) equipped with image software.

3D Areal surface texture parameters were acquired by an optical interferometer equipped by commercial software which provided all the parameters defined in the ISO 25178 standard. A sampling area of $0.865 \mathrm{~mm} \times 0.865 \mathrm{~mm}$ was analyzed with a resolution of $1024 \times 1024$ pixels. The most significant parameters of the surface changes after the treatment were chosen by the "average and standard deviation method" proposed by Helmli et al. (Ref 28, 29). This method analyses based on the significance $S_{i}(\mathrm{Eq} 1)$ and threshold $\tau$ (Eq 2) values calculated for each surface texture parameter,

$S_{i}=\frac{d\left(I_{i}^{\prime}, I_{i}^{\prime \prime}\right)}{\frac{1}{2}\left(\mu_{i}^{\prime}+\mu_{i}^{\prime \prime}\right)}$,

where $d\left(I_{i}^{\prime}, I_{i}^{\prime \prime}\right)$ is the highest difference between the confidence intervals $I_{i}$ and $\mu_{i}$ is the average of each parameter for the untreated (') and nitrided (') surfaces. The significance $S_{i}$ represents which parameter was more sensitive between the initial and the final surface condition. The threshold value $(\tau)$ was calculated by solving the quadratic equation for $\tau$ :

$\frac{\left(\tau-\mu_{i}^{\prime \prime}\right)^{2}}{2 \sigma_{i}^{\prime \prime}}-\frac{\left(\tau-\mu_{i}^{\prime}\right)^{2}}{2 \sigma_{i}^{\prime}}=\frac{\sigma_{i}^{\prime}}{\sigma_{i}^{\prime \prime}}$,

where $\sigma_{i}^{\prime}, \sigma_{i}^{\prime \prime}$ are the standard deviation of each surface parameter for the untreated and nitrided conditions, respectively. The threshold value is, in fact, the limit value of each roughness parameter used to differentiate between the surface conditions.

A diffractometer with radiation $\mathrm{CuK}-\alpha \quad(\lambda=1.5406 \AA)$ using the $\theta-2 \theta$ Bragg-Brentano configuration, a current of $30 \mathrm{~mA}$, a voltage of $40 \mathrm{kV}$ and a scan rate of $0.02 \% \mathrm{~s}$ was used to scan the XRD patterns from $20^{\circ}$ to $120^{\circ}(2 \theta)$. Also, the JCPDS cards were used for identifying the phase constituents: 00-006-0696 for ferrite, 01-071-4649 for austenite, 83-0875 for iron nitride $\gamma^{\prime}-\mathrm{Fe}_{4} \mathrm{~N}$ and $83-0877$ for iron nitride $\varepsilon-\mathrm{Fe}_{3} \mathrm{~N}$. The hardness of untreated and treated surfaces samples was measured with a microhardness tester with a Vickers indenter under load of $490 \mathrm{mN}\left(\mathrm{HV}_{0.05}\right)$ for $10 \mathrm{~s}$. Fifteen indentations on each phase were taken. Before performing the test, the samples were electrochemical etched as previously described.

\subsection{Electrochemical Corrosion Studies}

Corrosion behavior of untreated and plasma-nitrided samples was studied using potentiodynamic polarization technique in $3.5 \mathrm{wt} . \% \mathrm{NaCl}$ solution using a portable potentiostat with a reference electrode of $\mathrm{Ag} / \mathrm{AgCl}$ ( $\mathrm{KCl}$ saturated) and graphite as the counter electrode. This instrument has built-in software for data analysis. A specimen area of $0.5027 \mathrm{~cm}^{2}$ was exposed to $70 \mathrm{~mL}$ of solution on a flat electrochemical acrylic cell. After stabilizing the open-circuit potential (OCP) for $30 \mathrm{~min}$, the potentiodynamic polarization test was carried out by sweeping at a scan rate of $1 \mathrm{mV} / \mathrm{s}$, from - 300 to $1500 \mathrm{mV}$ for untreated samples and from -600 to $1500 \mathrm{mV}$ for nitrided ones. The reverse scan initiated at $1500 \mathrm{mV}$ on the cathodic direction. This test was repeated at least three times for each sample condition. All the potentials indicated in this work were compared to $\mathrm{Ag} / \mathrm{AgCl}$ ( $\mathrm{KCl}$ saturated). The PSTrace software was used to carry out the tests and to calculate the corrosion current density $\left(i_{\text {corr }}\right)$ and the corrosion potential $\left(E_{\text {corr }}\right)$ values.

Table 1 Chemical composition (wt.\%) of UNS S32205 duplex stainless steel

\begin{tabular}{lccccccc}
\hline Cr & Ni & Mo & C & Si & Mn & Fe (balance) \\
\hline $22.10 \%$ & $5.2 \%$ & $2.77 \%$ & $0.01 \%$ & $0.44 \%$ & $0.75 \%$ & $0.002 \%$ \\
\hline
\end{tabular}


The $i_{\text {corr }}$ value was used to calculate the corrosion rate (CR) according to ASTM G102-89 standard (Ref 30), considering the dimensionless equivalent weight $(\mathrm{EW}=25.874)$ and density $\left(\rho=7.69 \mathrm{~g} / \mathrm{cm}^{3}\right)$ of the UNS S32205. The passivation current density ( $\left.i_{\text {pass }}\right)$ corresponds to the arithmetic average of current densities throughout the passive region. Finally, the pitting nucleation $\left(E_{\mathrm{p}}\right)$ and repassivation $\left(E_{\mathrm{R}}\right)$ potentials were determined from the polarization curves according to the methodology proposed by Esmailzadeh et al. and Shoesmith (Ref 31, 32).

In order to study the evolution of some electrochemical features on nitrided samples, potentiostatic tests were carried out. Therefore, linear polarizations were done until the final potentials $0.7,0.9,1.0,1.05,1.1,1.15,1.2$ and $1.35 \mathrm{~V}$, followed by potentiostatic polarization at the chosen potential for $1 \mathrm{~h}$. These tests were performed under the same conditions as the potentiodynamic polarization tests. After the electrochemical studies, the corroded area was analyzed by OM and by scanning electron microscope (SEM), which was operated at $20.000 \mathrm{kV}$. The SEM was coupled with an energy-dispersive $\mathrm{x}$ ray analysis (EDX) used to identify the element partitioning in the duplex microstructure, according to Weber and Uggowitzer (Ref 33).

\section{Results and Discussion}

Typical cross-sectional micrograph of the plasma-nitrided UNS S32205 is shown in Fig. 1. The measured thickness value of this thin nitrided layer was $4.5 \pm 0.5 \mu \mathrm{m}$. This layer was uniform, and it was difficult to measure the thickness of the layers formed on top of the individual phases; hence, this is not mentioned. The nitrided layer formed on top of the austenite grains was denoted as $\gamma_{\mathrm{N}}^{\gamma}$ and that formed on top of the ferrite grains as $\gamma_{\mathrm{N}}^{\alpha}$, and this nomenclature will be discussed later. Under similar treatment conditions $\left(380{ }^{\circ} \mathrm{C}, 10 \mathrm{~h}\right.$ and a gas mixture consisting of $25 \% \mathrm{~N}_{2}$ and $75 \% \mathrm{H}_{2}$ ) and using the active screen nitriding technique, Pintaúde et al. (Ref 4) obtained $1.62 \pm 0.26 \mu \mathrm{m}$ nitrided layer thickness on the same DSS. Alphonsa et al. (Ref 6) reported nitrided layers with different thicknesses in each phase, 3.2 and $1.8 \mu \mathrm{m}$ in ferrite and austenite phase, respectively, when the UNS S32205 was

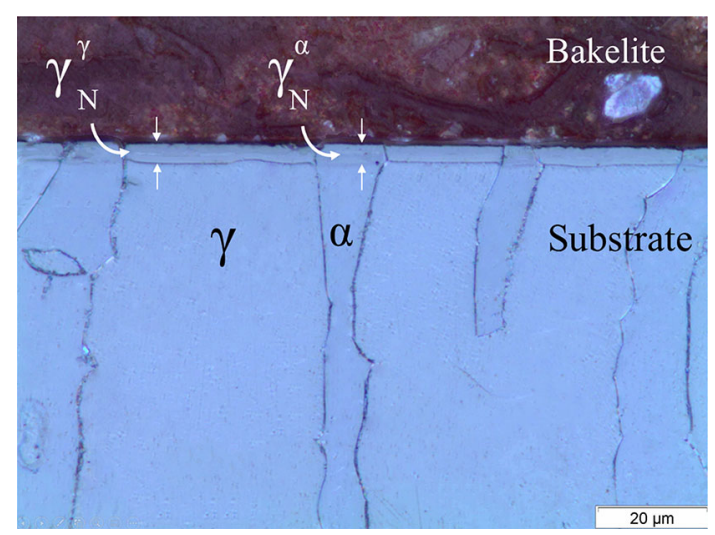

Fig. 1 Cross-sectional OM images of UNS S32205 plasma nitrided at $380{ }^{\circ} \mathrm{C}, 10 \mathrm{~h}$ and $25 \% \mathrm{~N}_{2}-75 \% \mathrm{H}_{2}$ atmosphere (etching with $10 \%$ oxalic acid) plasma nitrided for $4 \mathrm{~h}$ at $400{ }^{\circ} \mathrm{C}$ and a gas mixture consisting of $80 \% \mathrm{~N}_{2}$ and $20 \% \mathrm{H}_{2}$.

XRD patterns of untreated and nitrided specimens of UNS S32205 are shown in Fig. 2. The pattern of untreated sample revealed the diffraction peaks corresponding to the crystallographic planes $(h k l)$ of ferrite and austenite phases, as listed in Table 2. The pattern for the nitrided specimen showed a significant drop of the ferrite and austenite peaks; in addition, it exhibited two new peaks located at $2 \theta=41.24^{\circ}$ and $2 \theta=46.08^{\circ}$. Those peaks are attributed to the nitrogenexpanded austenite phase $\left(\gamma_{\mathrm{N}}\right)$ (Ref 1-7). These new peaks are broad in nature, and they are positioned at lower angles than the original austenite peaks in the untreated pattern (Fig. 3). This increase in the austenite lattice parameter occurs due to supersaturation of nitrogen solid solution in the face-centered cubic (FCC) structure (Ref 8).

Earlier studies reported the transformation of the ferritic phases into the nitrogen-expanded austenite structure due to the nitrogen gammagenic effect (Ref 4, 6, 9, 10). However, some researches state that low-temperature plasma nitriding promotes the transformation of the ferrite and austenite phases of the untreated DSS, into expanded austenite $\left(\gamma_{\mathrm{N}}\right)$ and expanded ferrite $\left(\alpha_{N}\right)$, respectively (Ref 5,7$)$. According to Pinedo et al. and Tschiptschin et al., the expanded ferrite phase was evidenced as a broad and low-intensity peak in the XRD spectra, located at $2 \theta \approx 44^{\circ}$ y $2 \theta \approx 64^{\circ}$ (Ref 5, 7). Nowadays, $\alpha_{\mathrm{N}}$ phase is not fully understood and some controversy remains regarding its identification. Discussion around these discrepancies goes beyond the objectives of this work. According to the XRD spectra of the nitrided DSS (Fig. 2 and 3), it is difficult to infer the existence of the $\alpha_{\mathrm{N}}$ phase, but it would be an interesting topic for future research. Therefore, the nomenclature followed in this work is expanded austenite coming from the previous austenite grains $\left(\gamma_{\mathrm{N}}^{\gamma}\right)$ and expanded austenite originated from the previous ferrite grains $\left(\gamma_{\mathrm{N}}^{\alpha}\right)$, as shown in Fig. 1.

Furthermore, the XRD spectra of nitrided samples revealed peaks attributed to iron nitrides $\gamma^{\prime}-\mathrm{Fe}_{4} \mathrm{~N}$ and $\varepsilon-\mathrm{Fe}_{3} \mathrm{~N}$, listed in Table 2 and indicated in Fig. 2 and 3. Using this $\mathrm{x}$-ray diffraction analysis conditions, no peaks corresponding to chromium nitrides precipitates were identified. The formation of a nitrided layer composed of nitrogen supersaturated phase without chromium nitrides is one of the most advantageous

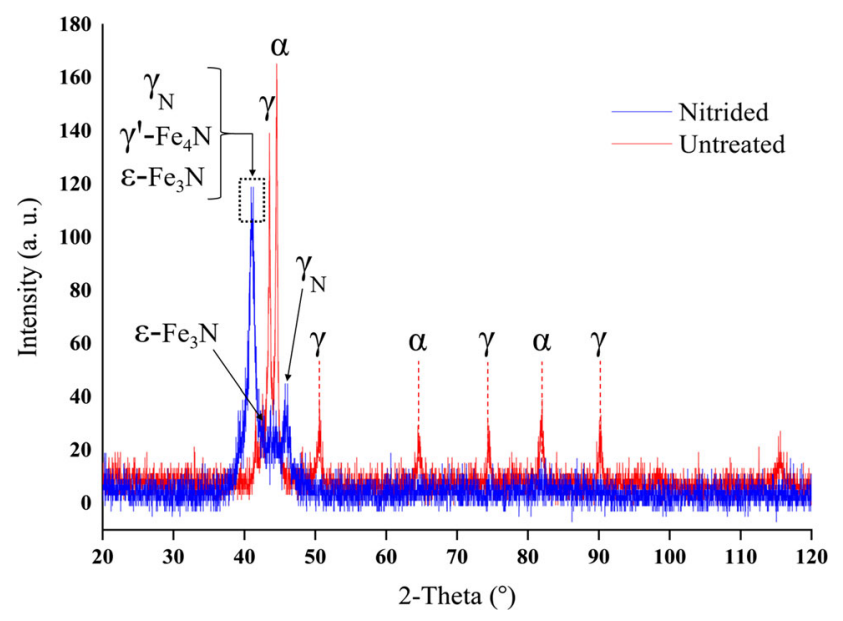

Fig. 2 XRD patterns of untreated and nitrided UNS S32205 
Table 2 Phase identification, diffraction angles and Miller index

\begin{tabular}{llcc}
\hline Condition & Phase & $\mathbf{2 \theta},^{\circ}$ & $(\boldsymbol{h} \boldsymbol{k})$ \\
\hline \multirow{2}{*}{ Untreated } & $\gamma$ & 43.52 & $(111)$ \\
& $\alpha$ & 44.54 & $(110)$ \\
& $\gamma$ & 50.58 & $(200)$ \\
& $\alpha$ & 64.76 & $(200)$ \\
& $\gamma$ & 74.5 & $(210)$ \\
& $\alpha$ & 82.42 & $(211)$ \\
& $\gamma$ & 90.3 & $(311)$ \\
Nitrided & $\alpha$ & 115.6 & $(310)$ \\
& $\varepsilon-\mathrm{Fe}_{3} \mathrm{~N}$ & 40.97 & $(002)$ \\
& $\gamma^{\prime}-\mathrm{Fe}_{4} \mathrm{~N}$ & 41.17 & $(111)$ \\
& $\gamma_{\mathrm{N}}$ & 41.24 & $(111)$ \\
& $\varepsilon-\mathrm{Fe}_{3} \mathrm{~N}$ & 43.42 & $(110)$ \\
& $\gamma_{\mathrm{N}}$ & 46.08 & $(200)$ \\
\hline
\end{tabular}

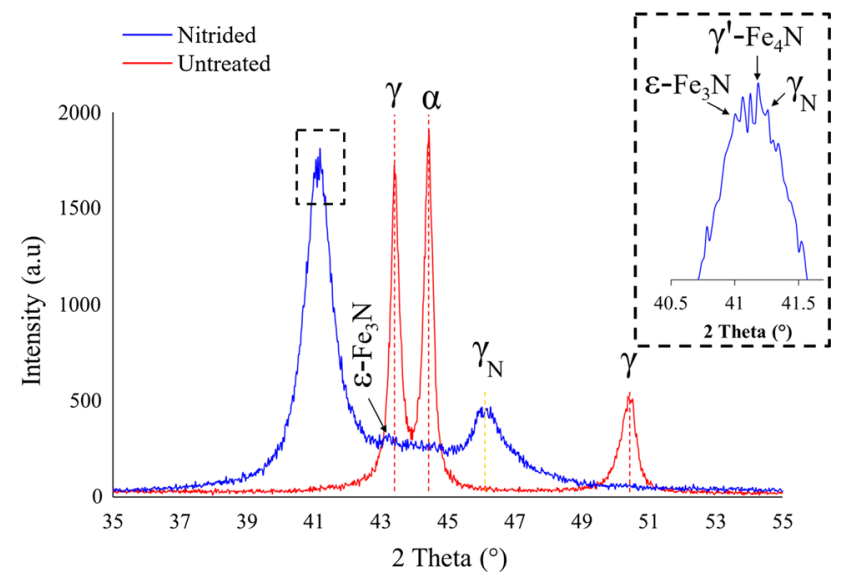

Fig. 3 Detail of the XRD patterns ranging from $35^{\circ}$ to $55^{\circ}$ of untreated and nitrided UNS S32205

characteristics of low-temperature plasma nitriding of DSS, as it is evidenced in numerous studies (Ref 1-7, 9, 13, 14).

Figure 4 shows the Vickers surface hardness values resulting from the individual phases before and after nitriding. The indentations marks left by the Vickers indenter are shown in Fig. 4(b) and (c). No significant differences were observed in the measured values for the ferritic $\left(355 \pm 18 \mathrm{HV}_{0.05}\right)$ and austenitic $\left(368 \pm 22 \mathrm{HV}_{0.05}\right)$ phases before treatment. Similar results were obtained on other studies, where the hardness values for both phases were close together in the UNS S32205 steel (Ref 6, 11, 15). Besides, hardness was significantly enhanced due to the formation of the expanded phase. The hardness of the nitrided surface was measured separately on top of the "previous" austenite grains $\left(\gamma_{\mathrm{N}}^{\mathrm{k}}\right)$ and the "previous" ferrite grains $\left(\gamma_{\mathrm{N}}^{\alpha}\right)$, as shown in Fig. 4. In comparison with the untreated ferritic and austenitic phases, the hardness of the nitrided layer increased 3.8 and 2.6 times for expanded $\gamma_{\mathrm{N}}^{\alpha}$ and expanded $\gamma_{\mathrm{N}}^{\mathrm{k}}$, respectively.

In the literature, many studies performed hardness measurements from random indentations on the plasma-nitrided surface without distinguishing the hardness value of each phase in DSS (Ref 1-3, 10, 13, 14). All of them obtained a hardness increase due to the interstitial solid solution strengthening. For the same material (UNS S32205), two different works reported higher
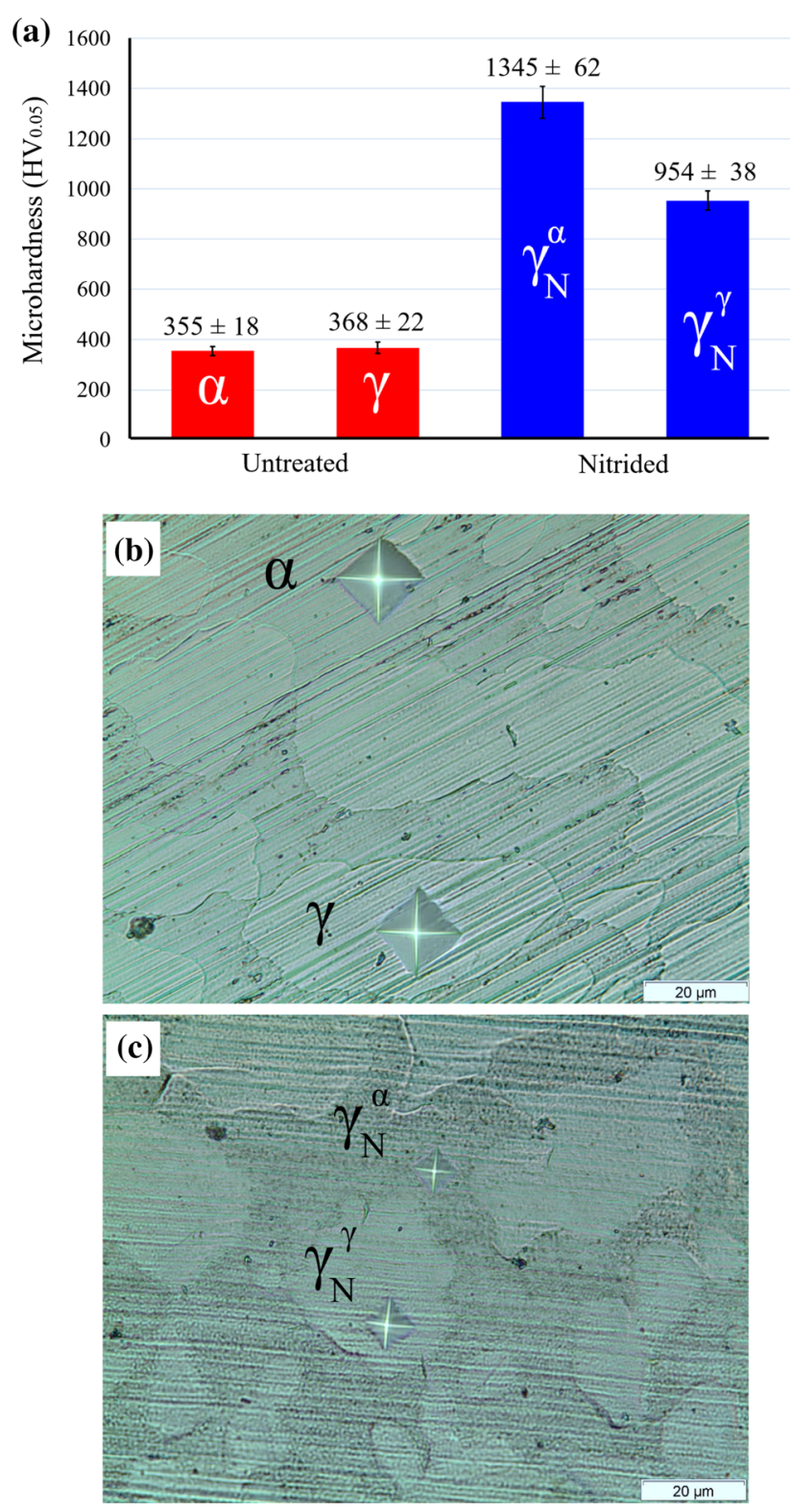

Fig. 4 Surface microhardness values (a) and Vickers indentations marks in the phases of duplex steel samples (100X): untreated (b) and nitrided (c)

hardness values for the modified ferritic phases at nitriding temperature of $400{ }^{\circ} \mathrm{C}(\operatorname{Ref} 5,6)$. Despite this, Pintaúde et al. (Ref 4) found that the modified austenitic phases had higher hardness after nitriding at $380{ }^{\circ} \mathrm{C}$ for $10 \mathrm{~h}$. In the referenced works (Ref 4-6), the hardness differences are attributed to the higher nitrogen content in the hard modified phase, which produces high tensions in the crystal lattice with the introduction of these interstitial atoms. Nevertheless, in the present work, the outstanding hardness of expanded $\gamma_{\mathrm{N}}^{\alpha}$ grains $\left(1345 \pm 62 \mathrm{HV}_{0.05}\right)$ compared to the $\gamma_{\mathrm{N}}^{\mathrm{k}}$ grains $(954 \pm 38$ $\left.\mathrm{HV}_{0.05}\right)$ could be related to the existence of the iron nitrides $\left(\gamma^{\prime}-\right.$ $\mathrm{Fe}_{4} \mathrm{~N}$ and $\varepsilon-\mathrm{Fe}_{3} \mathrm{~N}$ ) revealed in the XRD spectra (Fig. 2 and 3). According to other studies, iron nitrides mainly precipitated in the modified ferrite grains in the nitrided layer, resulting in higher hardness values in this modified phase $(\operatorname{Ref} 7,9)$.

The surface topography of the samples before and after nitriding treatment was analyzed using the interferometry 
technique and following the methodology described in section 2.The parameters skewness $\left(S_{\mathrm{sk}}\right)$, maximum peak height $\left(S_{\mathrm{p}}\right)$ and texture aspect ratio $\left(S_{\mathrm{tr}}\right)$ are the $3 \mathrm{D}$ surface texture parameters that best indicate the change in topography with the plasma treatment. All the values are shown in Table 3 and Fig. 5.

As shown in Fig. 5, these parameters have well-differentiated values between initial (untreated) and final (nitrided) surface conditions, with the calculated threshold value being between them. In addition, they were the surface parameters with the highest significance value, thus indicating which surface characteristic changed the most with the nitriding treatment. With these three conditions fulfilled, they effectively represent the parameters that best indicate the topography changes caused by the treatment.

According to Table 3, the negative value of $S_{\mathrm{sk}}$ for the untreated surface represents the predominance of surface valleys, while positive values represent the predominance of peaks as a result of the nitriding treatment. On the other hand, $S_{\text {tr }}$ values close to 0 indicate surface anisotropy, which agrees with the surface preparation prior to treatment, as it can be observed in the directionality of the ground marks in Fig. 6(a), whereas $S_{\text {tr }}$ values close to 1 represent a more isotropic surface as shown in Fig. 6(b), as a result of the random bombardment of species during the plasma sputtering and nitriding processes (Ref 6, 29). Finally, $S_{\mathrm{p}}$ parameter agrees with the results of the skewness parameter, evidencing that nitriding treatment changed the surface to a more isotropic topography with predominance of peaks.

The polarization curves shown in Fig. 7 correspond to the potentiodynamic sweeps of UNS S32205 untreated and nitrided. Corrosion current density, corrosion potential, passivation current density, pitting nucleation potential, repassivation potential and corrosion rate values of untreated and plasma-nitrided UNS S32205 are summarized in Table 4. These results are the arithmetic mean of at least three specimens in order to check the replicability; the scatter in the data is also reported.

After the nitriding treatment, the corrosion potential $\left(E_{\text {corr }}\right)$ decreased, while the corrosion current density $\left(i_{\text {corr }}\right)$ increased, both with respect to the untreated specimen. These results represent a loss of nobility in the general corrosion in the nitrided steel. The average passivation current density $\left(i_{\text {pass }}\right)$ is two orders of magnitude higher, indicating that the passive layer of nitrided surface was less protective. However, according to the literature, current densities of the order of $\mathrm{nA} / \mathrm{cm}^{2}$ to tens of $\mathrm{mA} / \mathrm{cm}^{2}$ are considered passivation densities (Ref 32). Previous works on nitrided DSS (UNS S31803 and UNS S32205) obtained nobler or equal corrosion potentials for nitrided steel compared to the untreated material (Ref 2, 4, 6, 14). These studies reported passivation current densities of the untreated material in the order of magnitude of $10^{0}$ to $10^{1} \mu \mathrm{A} /$ $\mathrm{cm}^{2}$, while the average current density of nitrided samples can be in the same order of magnitude and larger up to two orders.

The polarization curves for the nitrided specimens (Fig. 7) also show the displacement of the pitting nucleation potential $\left(E_{\mathrm{P}}\right)$ and repassivation potential $\left(E_{\mathrm{R}}\right)$ to larger potentials with the consequent reduction in the hysteresis loop. The above observations manifest the better localized corrosion resistance of the nitrided UNS S32205. It is important to note that none of

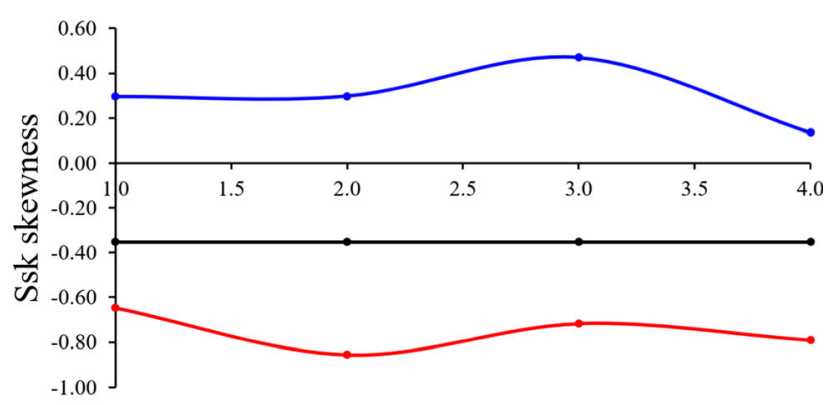

(a)

Samples

$\rightarrow$ Ssk Untreated $\rightarrow$-Ssk Nitrided $\rightarrow$-Threshold
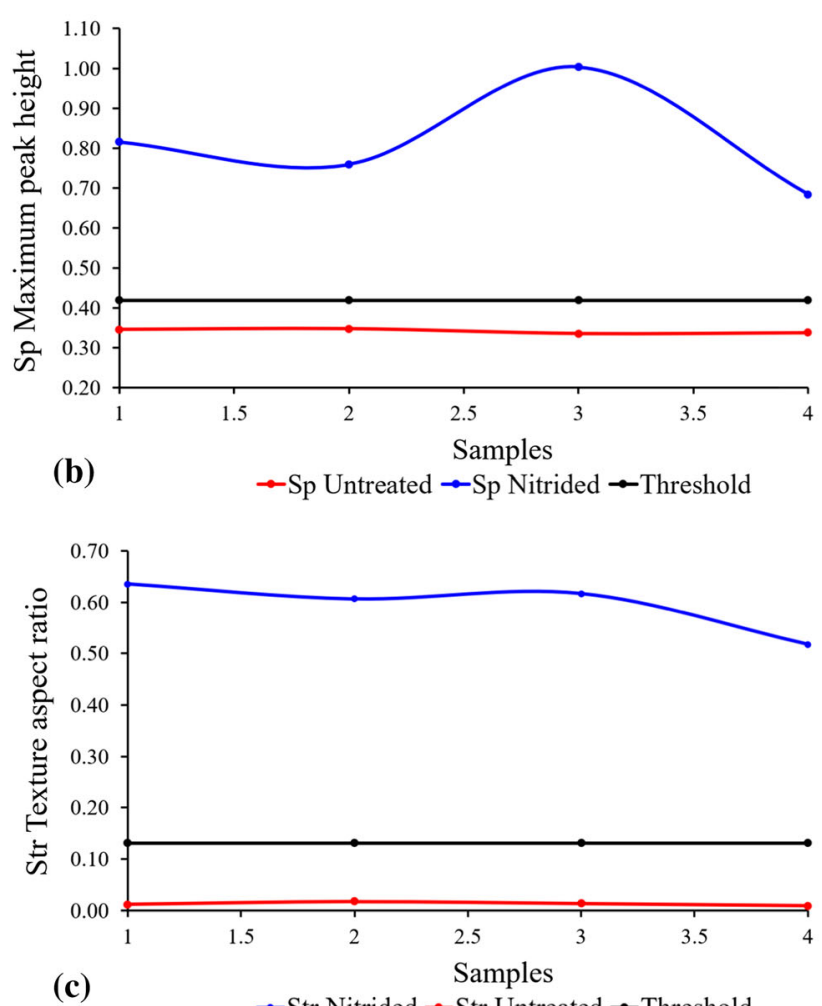

Fig. 5 Graphical representation of $S_{\mathrm{sk}}$ (a), $S_{\mathrm{p}}$ (b) and $S_{\text {tr }}$ (c) parameters and their threshold values before and after nitriding

Table 3 Values of $S_{\mathrm{sk}}, S_{\mathrm{p}}$ and $S_{\mathrm{tr}}$ surface texture parameters and their significance and threshold calculated values

\begin{tabular}{lcccr}
\hline Parameter & Significance & Threshold & Untreated & Nitrided \\
\hline$S_{\text {sk }}$ & 6.64 & -0.35 & $-0.75 \pm 0.09$ & $0.3 \pm 0.14$ \\
$S_{\mathrm{p}}, \mu \mathrm{m}$ & 1.31 & 0.42 & $0.341 \pm 0.006$ & $0.82 \pm 0.14$ \\
$S_{\text {tr }}$ & 2.29 & 0.13 & $0.013 \pm 0.004$ & $0.59 \pm 0.05$ \\
\hline
\end{tabular}


these corroded samples (untreated and nitrided) presented crevice corrosion. Instead, general corrosion and some pits were observed in the corroded surface of both samples.

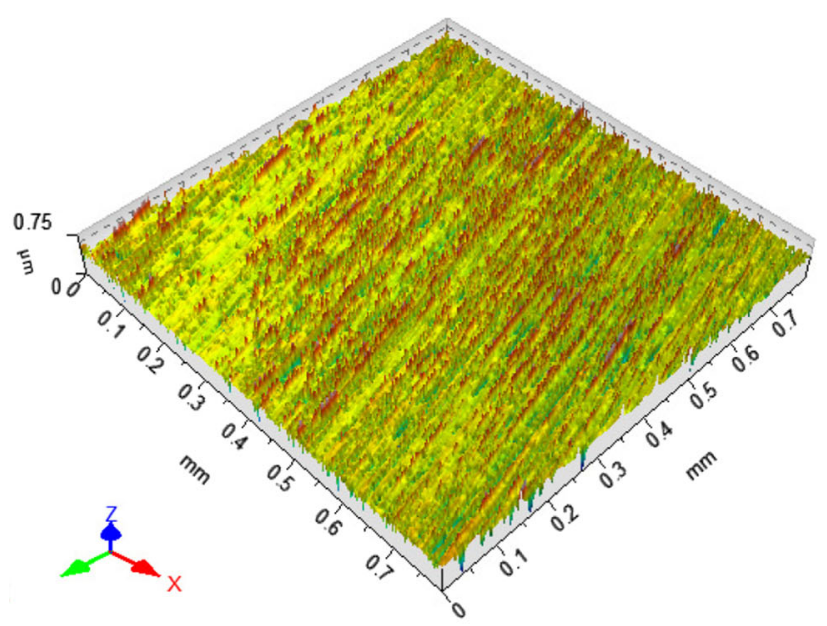

(a)

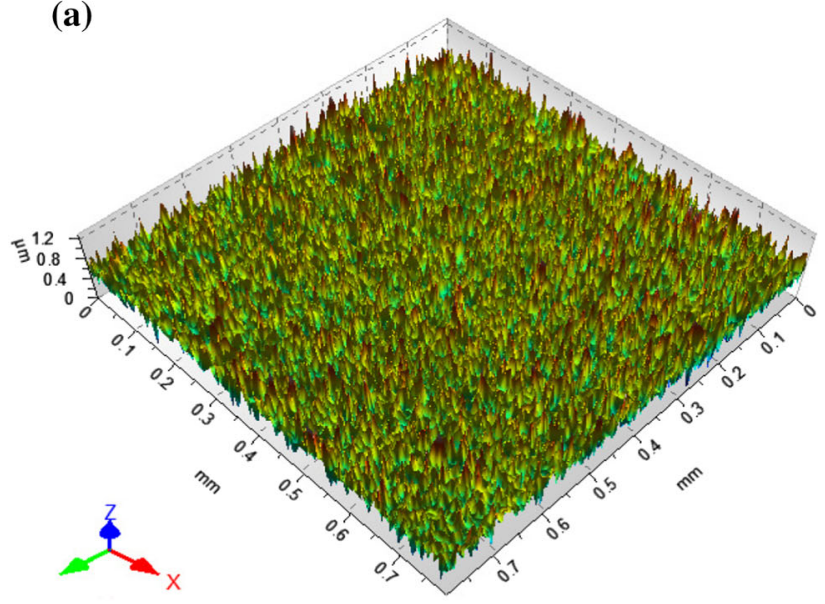

(b)

Fig. 6 Topographic 3D profile of UNS S32205: (a) untreated and (b) nitrided
The positive effect of nitrogen on improving the pitting corrosion resistance was already confirmed by Baba et al. (Ref 12) and other researches in DSS plasma nitrided (Ref 1-4, 6). Besides this effect, the influence of surface roughness in the localized corrosion cannot be neglected. According to Tang et al. (Ref 26), a rougher surface increases the possibility of stable pitting grow. In the present investigation, untreated surfaces showed predominance of valleys structures demonstrated by the parameters $S_{\mathrm{sk}}=-0.75 \pm 0.09$ and $S_{\mathrm{p}}(\mu \mathrm{m})=$ $0.341 \pm 0.006$. The valleys structures could promote cavities more occluded and with the ability to maintain the internal electrochemical pit environment (Ref 26). This could also contribute to the lower pitting corrosion resistance of the rougher surface, i.e., the untreated surface, which exhibited higher hysteresis loop and lower $E_{\mathrm{P}}$ and $E_{\mathrm{R}}$ potentials indeed.

The potentiodynamic curves of the nitrided samples (Fig. 7) exhibit a hillside at the end of the passivation region and just before the transpassive region. This feature was already evidenced on other studies of plasma-nitrided stainless steels as those developed by Chiu et al., Pereira et al., Alphonsa, Raja and Mukherjee, Li, Dou and Dong and Lee, in DSS, the work of Spies et al. in austenitic steel and Pires et al. in martensitic steel (Ref 2, 3, 6, 13-17). In none of these studies, a discussion regarding this behavior is presented.

Table 4 Summary of $i_{\text {corn }}, E_{\text {corn }}, i_{\text {pass, }}, E_{\mathrm{p}}, E_{\mathrm{R}}$ and corrosion rate (CR) of untreated and plasma-nitrided UNS S32205 steel

\begin{tabular}{lcc}
\hline & \multicolumn{2}{c}{ Duplex stainless steel UNS S32205 } \\
\cline { 2 - 3 } & Untreated & Nitrided \\
\hline$i_{\text {corr }}, \mu \mathrm{A} / \mathrm{cm}^{2}$ & $0.22 \pm 0.12$ & $0.98 \pm 0.63$ \\
$E_{\text {corr }}, \mathrm{V}$ & $0.15 \pm 0.04$ & $-0.33 \pm 0.08$ \\
$i_{\text {pass }}, \mu \mathrm{A} / \mathrm{cm}^{2}$ & $4.7 \pm 1.3$ & $268 \pm 40$ \\
$E_{\mathrm{p}}, \mathrm{V}$ & $1.17 \pm 0.05$ & $1.285 \pm 0.005$ \\
$E_{\mathrm{R}}, \mathrm{V}$ & $1.10 \pm 0.16$ & $1.21 \pm 0.01$ \\
$\mathrm{CR}, \mathrm{mm} /$ year & $0.002 \pm 0.001$ & $0.011 \pm 0.007$ \\
Standard deviation in data is shown & \\
\hline
\end{tabular}

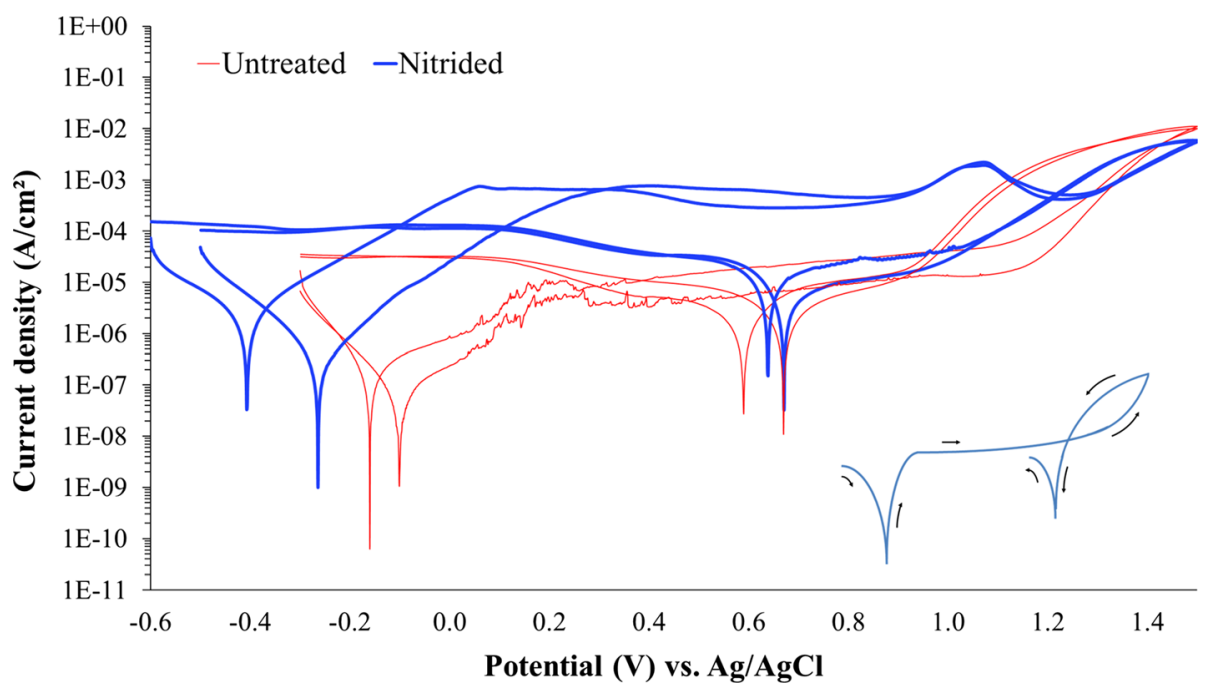

Fig. 7 Potentiodynamic polarization curves of untreated and nitrided UNS S32205 (Scan rate $1 \mathrm{mV} / \mathrm{s}, 3.5 \mathrm{wt} . \% \mathrm{NaCl}$ ) 


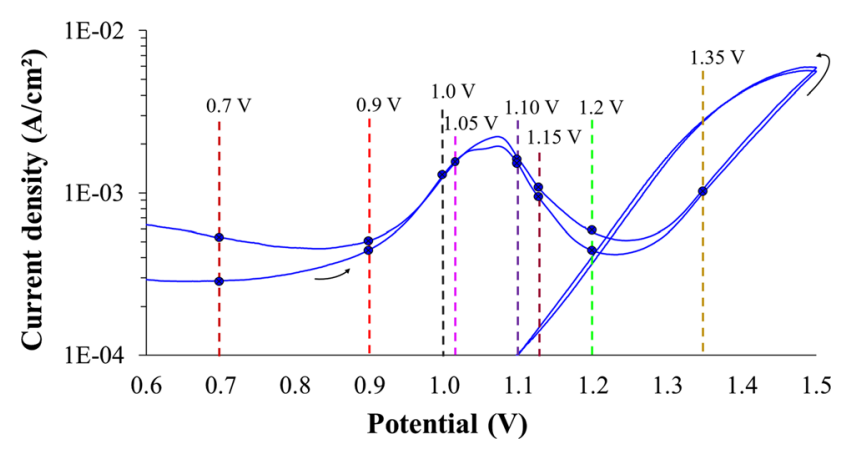

Fig. 8 Detail of the potentiodynamic polarization curves of nitrided UNS S32205. The chosen potentials for potentiostatic tests are identified by dotted lines that cross over the polarization curves at the potentials: $0.7,0.9,1.0,1.05,1.1,1.15,1.2$ and $1.35 \mathrm{~V}$

Figure 8 shows a zoomed view of the polarization curves of nitrided samples between 0.7 and $1.5 \mathrm{~V}$. The hillside is evidenced between the potentials 0.9 and $1.2 \mathrm{~V}$, prior to the hysteresis loop. The hillside is characterized by a continuous increase followed by a decrease in the current density. In order to study the evolution of this phenomena, different potentials (identified in Fig. 8) were chosen for potentiostatic analysis. The passivation $(0.7 \mathrm{~V})$ and transpassivation $(1.35 \mathrm{~V})$ potentials were also chosen for comparative purposes.

During the potentiostatic tests, the variation of the current as a function of time was recorded. These curves are presented in Fig. 9(a).

The current-time curves (Fig. 9a) of the tests developed in the potential range from 0.7 to $1.2 \mathrm{~V}$ showed a similar trend: They started at current values around $2000 \mu \mathrm{A}$, in the first $300 \mathrm{~s}$ they suddenly decreased, and then they maintained almost constant current values until the end of the test. The curve of the test performed at $1.35 \mathrm{~V}$ behaved differently from the others, stabilizing at higher current values. According to the cyclic polarization curves (Fig. 7), this potential is located in the transpassivation region, where the current increase is usually attributed to the passive layer dissolution and localized corrosion processes. In addition, during this test at $1.35 \mathrm{~V}$, many bubbles were formed on the corroded surface, which is related to the decomposition of water, a reaction that also contributed to the current increase.

Figure 9 (b) shows a zoomed view of the current-time curves performed between potentials 0.7 and $1.15 \mathrm{~V}$. In those curves, it could be observed current transients or fluctuations all along the time lapse, being greater at the potentials 1.05 and $1.15 \mathrm{~V}$. At the potential $1.05 \mathrm{~V}$, these signals had well-defined periodic behavior from $1200 \mathrm{~s}$ until the end of the test. These fluctuations had a variable amplitude ranging from 0.05 to $3.0 \mu \mathrm{A}$ and a period between 3 and $5 \mathrm{~s}$. This potential corresponds to the top of the hillside (Fig. 8). In comparison, the current fluctuations of the tests developed at the $1.15 \mathrm{~V}$ potential were variable from $200 \mathrm{~s}$ until the end of the test, presenting wide dispersion of both amplitude and period values.

Stainless steels in chloride-containing solutions have been evidenced electrochemical noise, transient signals or wellknown fluctuations in current when they were subjected to open-circuit potential condition, potentiodynamic polarization, anodic galvanostatic polarization and potentiostatic polarization (Ref 18, 22-24). These signals reflect the initiation, growth and
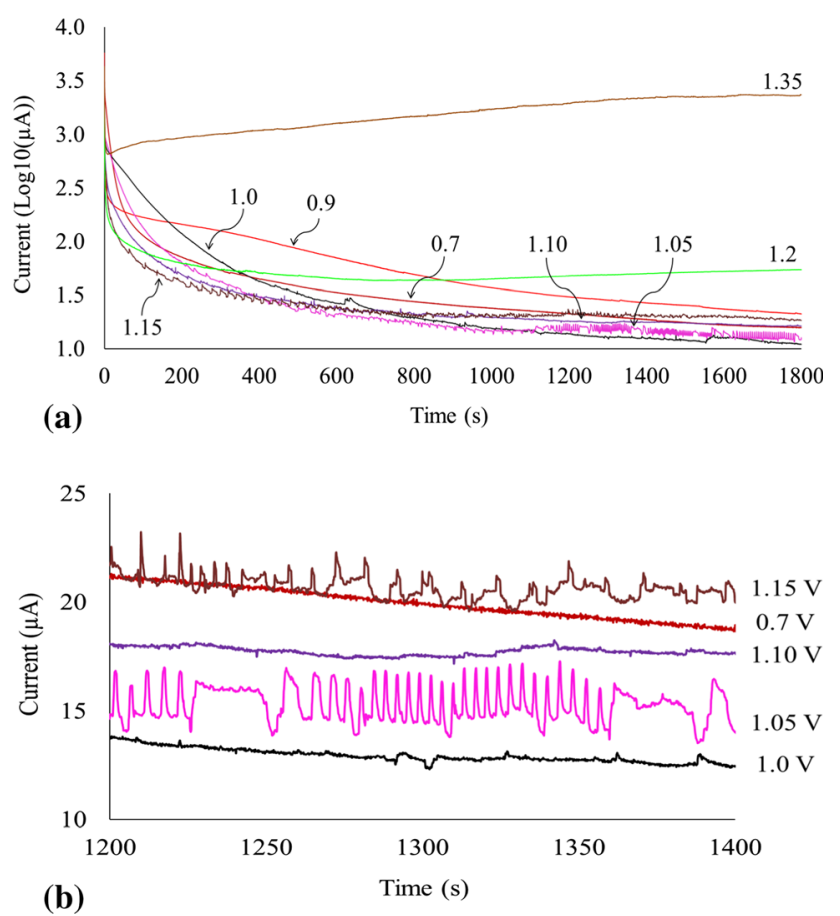

Fig. 9 Results of potentiostatic tests set at the chosen potentials in the passive-to-transpassive transition of nitrided UNS S32205. (a) Current versus time curves of all the potentiostatic conditions; (b) detail between 1200 and $1400 \mathrm{~s}$ of potentiostatic tests hold at 0.7 , $1.0,1.05,1.10$ and $1.15 \mathrm{~V}$

repassivation processes of precursor pits, which are called metastable pits. According to Laycock, Moayed and Newman, the manifestation of these transient signals, even at temperature conditions lower than the critical pitting temperature (CPT) or also at potentials lower than the pitting potential, is an indication of these metastable phenomena (Ref 22). These current fluctuations can have ranges from tens of $\mathrm{pA}$ to tens of $\mu \mathrm{A}$ (above the average current) and a short duration of a few seconds, as reported on different austenitic stainless steels and DSS (Ref 22-27). Consequently, the fluctuations of the currenttime curves of the potentiostatic tests (Fig. 9b) are attributed to metastable pitting in the nitrided UNS S32205.

With the purpose of studying the phenomenology occurred during the potentiostatic tests, micrographs of the corroded surfaces after tests were analyzed in order to confirm the formation of metastable pits and to identify if other types of corrosion occurred. In this type of mounting, crevice corrosion can occur in the contact regions or boundaries between the sample and the corrosion cell. These boundaries were analyzed, whose micrographs are presented in Fig. 10.

The micrographs in Fig. 10 are divided by a dotted line drawn in the sample/cell contact regions. Consequently, the corroded surface that was exposed to the electrolytic solution is in the right side of each micrograph. The sample surface that was not in contact with the solution is in the left side. In the micrographs shown in Fig. 10(a)-(e) (potentials between 0.7 and $1.2 \mathrm{~V}$ ), it is possible to observe the non-formation of crevice corrosion; therefore, the formation of the hillside was not a consequence of this type of localized corrosion. Otherwise in Fig. 10(f), crevice formation in the boundary region is evidenced in addition to further general surface degradation. The corrosion attack seems deeper in one of the 

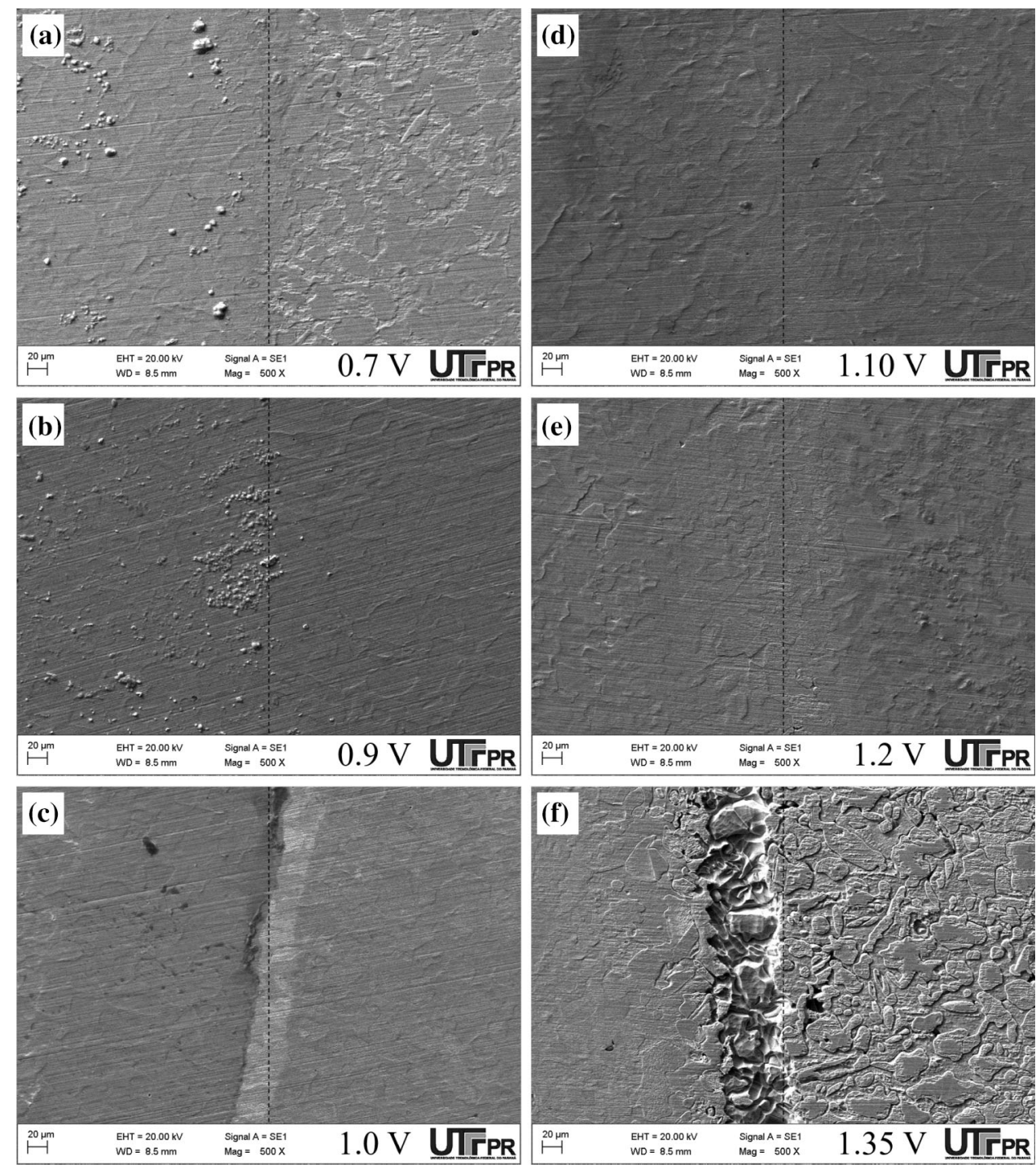

Fig. 10 SEM micrographs of nitrided samples (500X) after the potentiostatic tests hold at: (a) $0.7 \mathrm{~V}$; (b) $0.9 \mathrm{~V}$; (c) $1.0 \mathrm{~V}$; (d) $1.10 \mathrm{~V}$; (e) $1.2 \mathrm{~V}$; and (f) $1.35 \mathrm{~V}$. Surfaces comparison: right side corroded, left side not exposed to $3.5 \mathrm{wt} . \% \mathrm{NaCl}$ solution

phases. Crevice corrosion and high surface degradation observed in the sample polarized at the transpassive potential (1.35 V, Fig. 10f) certainly were part of the sources that contributed to the higher current values (Fig. 9a).

Once it was verified that there was no crevice corrosion in the potential range where the hillside was formed, the corroded surfaces were analyzed with the aim of detecting the formation of pits. Some micrographs of these surfaces are shown in Fig. 11, which demonstrated the presence of pits in all potentiostatic tests. It was identified by EDX in which expanded phase the pits nucleated preferentially, because the substitutional elements remain in the regions previously occupied by austenite and ferrite grains $(\operatorname{Ref} 4,6)$.

Low-temperature plasma nitriding studies on DSS report a non-uniform distribution of nitrogen in the nitrided layer, with differences between phases (Ref 2, 4, 6, 9). According to the Pitting Resistant Equivalent Number (PREN), the pitting corrosion resistance depends mainly on the chromium, molybdenum and nitrogen elements (Ref 19, 33). Hence, the unequal distribution of the elements in the phases could cause a difference in localized corrosion resistance between them. In fact, most of the pits nucleated in the expanded $\gamma_{\mathrm{N}}^{\alpha}$ phase and some pits nucleated in the phase boundaries between the expanded $\gamma_{\mathrm{N}}^{\gamma}$ and expanded $\gamma_{\mathrm{N}}^{\alpha}$ grains. Finally, few pits were found within the expanded $\gamma_{\mathrm{N}}^{\gamma}$ grains. To confirm the element partitioning in the nitrided UNS S32205, further research needs to be done in order to study the accurate chemical composition of the expanded phases from chemical analysis techniques, such as WDS and XPS.

In the micrographs of the tests conducted between the potentials 0.7 to $1.2 \mathrm{~V}$ (Fig. 11a-f), pits with dimensions not exceeding $5 \mu \mathrm{m}$ in diameter were observed. According to some studies, the size of the metastable pits did not exceed $10 \mu \mathrm{m}$ (Ref 18, 23, 26, 27). Therefore, the pits nucleated during potentiostatic tests can be considered metastable pits, which verifies the transient behavior observed in current curves as a function of time (Fig. 9b). When these metastable pits were subjected to potentials in the transpassivation region $(>1.2 \mathrm{~V})$, they became stable and severe pits as those observed in the micrographs of the potential tests at $1.35 \mathrm{~V}$ (Fig. $11 \mathrm{~g}$ and $\mathrm{h}$ ). In this test condition, the size of the pits was considerably larger than the pits formed at the other lesser 

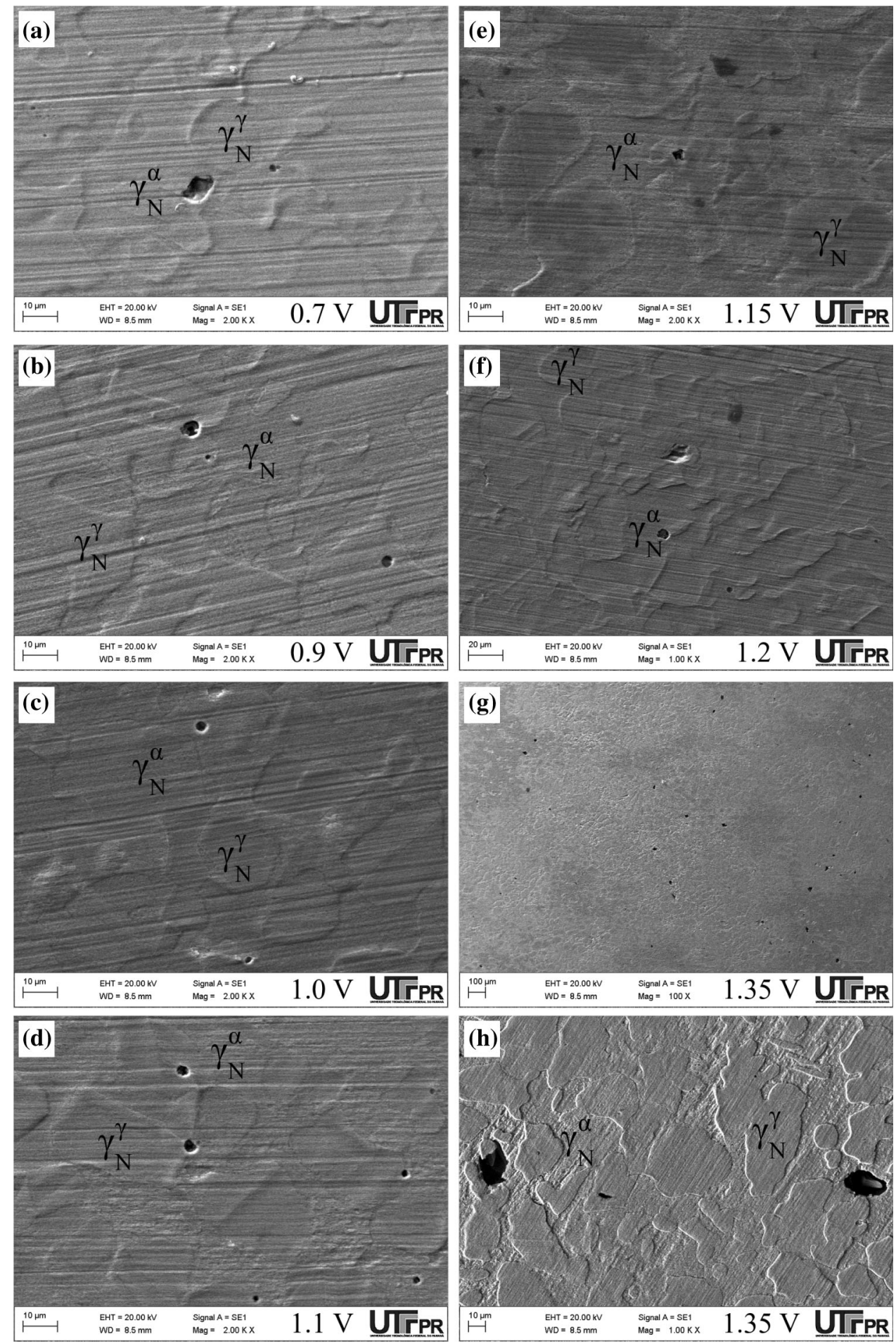

Fig. 11 SEM micrographs of nitrided samples after potentiostatic tests hold at: (a) $0.7 \mathrm{~V}$; (b) $0.9 \mathrm{~V}$; (c) $1.0 \mathrm{~V}$; (d) $1.10 \mathrm{~V}$; (e) $1.15 \mathrm{~V}$; (f) $1.2 \mathrm{~V}$; and (g) 1.35 ; (h) Detail of surface after potentiostatic test at $1.35 \mathrm{~V}$

potentials, having diameters up to $20 \mu \mathrm{m}$ (Fig. 11h). The fact that these metastable pits were formed and immediately repassivated, as evidenced by the transient signals, also agrees that the material was polarized in potentials smaller than the repassivation potential $\left(E_{\mathrm{R}}=1.21 \pm 0.01 \mathrm{~V}\right.$, Table 2$)$ and theoretically the material has the ability to repassivate the localized corrosion (Ref 10).
Besides the preferential nucleation of the metastable pits in the expanded $\gamma_{\mathrm{N}}^{\alpha}$ regions, it was also evidenced the greater susceptibility of corrosion attack in this phase. Figure 12(a) shows how some regions were preferentially attacked (dark regions: $\gamma_{\mathrm{N}}^{\alpha}$ ), while in the other expanded phase (light regions: $\gamma_{\mathrm{N}}^{\gamma}$ ) the corrosion was less evident. The precipitates observed in Fig. 12(b) were analyzed by EDX. This technique revealed that 

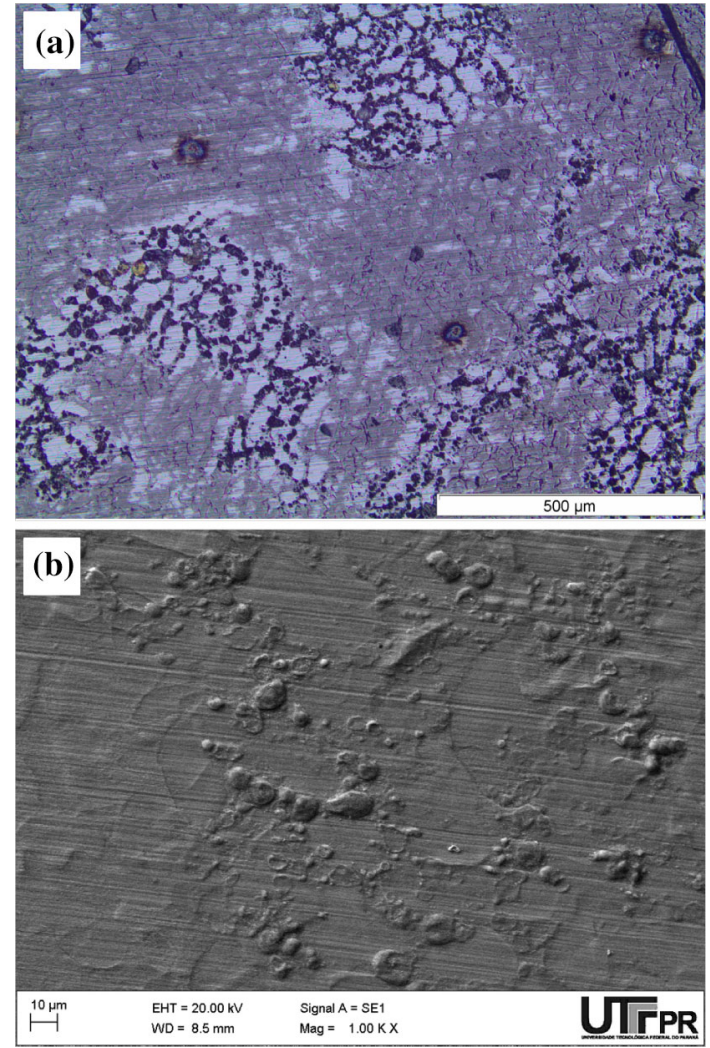

Fig. 12 Micrographs of corroded surfaces of nitrided specimens after potentiostatic tests (1.2 V): (a) OM and (b) SEM

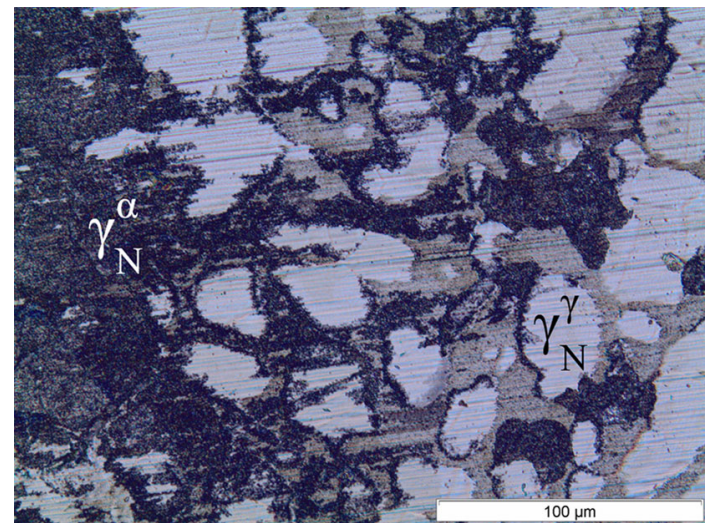

Fig. 13 OM micrograph of corroded surface of nitrided specimens after potentiostatic tests $(1.35 \mathrm{~V})$

they were probably corrosion products such as oxides and salts, due to the oxygen $(27.16 \%$ mass $)$ and chlorine contents measured (1.12\% mass).

Finally, it is shown in Fig. 13 the corroded surface after the potentiostatic test at $1.35 \mathrm{~V}$. In this figure is evidenced the preferential corrosion in the (dark) expanded $\gamma_{\mathrm{N}}^{\alpha}$ phase and in some grain boundaries between expanded phases. The intergranular corrosion could be caused by the formation of the galvanic cell as a consequence of the differences in corrosion resistance in the duplex biphasic morphology (Ref 19, 21, 26, 33).

Summarizing, the formation of the hillside on the passiveto-transpassive region in the nitrided UNS S32205 is a manifestation of the metastable pit nucleation. This type of pits evolves into stable pits at potentials higher than the repassivation potential, when the material is already in the transpassivation region. Additionally, it was evidenced that the expanded $\gamma_{\mathrm{N}}^{\alpha}$ regions and the grain boundaries are more susceptible to corrosion attack and pitting corrosion, in comparison with the expanded $\gamma_{\mathrm{N}}^{\gamma}$ phase.

\section{Conclusions}

Plasma nitriding was conducted on duplex stainless steel UNS S32205 at a temperature of $380{ }^{\circ} \mathrm{C}$ for $10 \mathrm{~h}$. Based on the experimental results, the following conclusions can be drawn:

- The plasma nitriding treatment of the UNS S32205 steel formed a layer thickness of $4.5 \pm 0.5 \mu \mathrm{m}$ composed of nitrogen-expanded austenite and iron nitrides $\left(\gamma^{\prime}-\mathrm{Fe}_{4} \mathrm{~N}\right.$ and $\left.\varepsilon-\mathrm{Fe}_{3} \mathrm{~N}\right)$ without chromium nitrides precipitates.

- The nitrided surface exhibited higher hardness values being 2.6 and 3.8 times in the expanded phases formed on top of austenite and ferrite grains, respectively, when compared with the untreated surfaces.

- The nitriding treatment produced a more isotropic topography with a predominance of peaks, confirmed by the values of the $3 \mathrm{D}$ surface texture parameters $S_{\mathrm{sk}}, S_{\mathrm{p}}$ and $S_{\text {tr. }}$

- The cyclic polarization tests revealed an improvement in localized corrosion resistance of nitrided steel, showing higher values of pitting $\left(E_{\mathrm{p}}\right)$ and repassivation $\left(E_{\mathrm{R}}\right)$ potentials and smaller hysteresis loop compared to the untreated condition.

- The hillside exhibited at the end of the passivation region of the nitrided specimens was a consequence of the nucleation of metastable pits between the potentials $0.9 \mathrm{~V}$ and $1.2 \mathrm{~V}$ (versus $\mathrm{Ag}-\mathrm{AgCl}$ ).

- Metastable pits preferentially nucleated in the expanded $\gamma_{\mathrm{N}}^{\alpha}$ phases, and they were identified by transient signals during potentiostatic tests, in addition to their diameter that does not exceed $5 \mu \mathrm{m}$.

- The expanded $\gamma_{\mathrm{N}}^{\alpha}$ phases and the grain boundaries of the nitrided UNS S32205 showed the highest corrosion susceptibility during the potentiostatic tests carried out at 1.2 and $1.35 \mathrm{~V}$.

\section{Acknowledgments}

The authors thank CNPq and CAPES Brazilian Funding Agencies for the scholarships awarded to Y. Núñez and O. Palma. The authors acknowledge the Multi-User Center for Materials Characterization (CMCM) of the UTFPR for SEM analysis. The authors also thank Fundación Universitaria Los Libertadores and Federal University of Technology - Paraná (UTFPR) for the financial support of this research.

\section{Open Access}

This article is licensed under a Creative Commons Attribution 4.0 International License, which permits use, sharing, adaptation, 
distribution and reproduction in any medium or format, as long as you give appropriate credit to the original author(s) and the source, provide a link to the Creative Commons licence, and indicate if changes were made. The images or other third party material in this article are included in the article's Creative Commons licence, unless indicated otherwise in a credit line to the material. If material is not included in the article's Creative Commons licence and your intended use is not permitted by statutory regulation or exceeds the permitted use, you will need to obtain permission directly from the copyright holder. To view a copy of this licence, visit http://creativecommons.org/licenses/by/4.0/.

\section{References}

1. K. Nagatsuka, A. Nishimoto, and K. Akamatsu, Surface Hardening of Duplex Stainless Steel by Low Temperature Active Screen, Surf. Coat. Technol., 2010, 205(1), p 295-299

2. L.H. Chiu, Y.Y. Su, F.S. Chen, and H. Chang, Microstructure and Properties of Active Screen Plasma, Mater. Manuf. Process., 2010, 25(5), p 316-323

3. J.O. Pereira, R. Oliveira, E. Hónorio, J.A. Moreto, R. Marinho, M. Dorigão, and L. Sgarbi, Wear and Corrosion Study of Plasma Nitriding F53 Super Duplex Stainless Steel, Mater. Res., 2016, 19(6), p 12411252

4. G. Pintaúde, A. Rovani, J.C. Klein das Neves, L.E. Lagoeiro, X. Li, and H. Dong, Wear and Corrosion Resistances of Active Screen Plasma-Nitrided Duplex Stainless Steels, J. Mater. Eng. Perform., 2019, 28(6), p 3673-3682

5. C.E. Pinedo, L.B. Varela, and A.P. Tschiptschin, Low-Temperature Plasma Nitriding of AISI, F51 Duplex Stainless Steel, Surf. Coat. Technol., 2013, 232, p 839-843

6. J. Alphonsa, V.S. Raja, and S. Mukherjee, Study of Plasma Nitriding and Nitrocarburizing for Higher Corrosion Resistance and Hardness of 2205 Duplex Stainless Steel, Corros. Sci., 2015, 100, p 121-132

7. A.P. Tschiptschin, L.B. Varela, C.E. Pinedo, X.Y. Li, and H. Dong, Development and Microstructure Characterization of Single and Duplex Nitriding of UNS S31803 Duplex Stainless Steel, Surf. Coat. Technol., 2017, 327, p 83-92

8. B.K. Brink, K. Stahl, T.L. Christiansen, and J. Oddershede, On the Elusive Crystal Structure of Expanded Austenite, Scr. Mater., 2017, 131(1), p 59-62

9. W. de Oliveira, B. Kurelo, D.G. Ditzel, F. Serbena, C. Foerster, and G. de Souza, On the S-Phase Formation and the Balanced Plasma Nitriding of Austenitic-Ferritic Super Duplex Stainless Steel, Appl. Surf. Sci., 2018, 434(15), p 1161-1174

10. J. Yan, T. Gu, S. Qiu, J. Wang, J. Xiong, and H. Fan, Phase Transformations During the Low-Temperature Nitriding of AISI, Duplex Stainless Steel, Metall. Mater. Trans. B, 2015, 43(3), p 1461-1470

11. J.E. May, C.A. Caldas de Souza, P.A.P. Nascente, P. Soares, C.M. Lepienski, and S.E. Kuri, Effect of Thermal Aging Conditions on the Corrosion Properties and Hardness of a Duplex Stainless Steel, Mater Res., 2010, 13(4), p 431-436

12. H. Baba, T. Kodama, and Y. Katada, Role of Nitrogen on the Corrosion Behavior of Austenitic Stainless Steels, Corros. Sci., 2002, 44(10), p 2393-2407

13. X. Li, W. Dou, and H. Dong, Combating the Tribo-Corrosion of LDX2404 Lean Duplex Stainless Steel by Low Temperature Plasma Nitriding, Lubricants, 2018, 6(93), p 1-12

14. I. Lee, Effect of CH4 Content on the Characteristics of Surface Layers of Low Temperature Plasma Nitrided 2205 Duplex Stainless Steel, Mater. Sci. Forum, 2016, 879, p 1074-1079
15. O. Palma, Y. Núñez, J. Ribeiro, P. Borges, Comportamento tribológico do aço inoxidável duplex UNS S32205 submetido a nitretação a plasma em baixas temperaturas (Tribological properties of low temperature plasma nitrided duplex stainless steel UNS S32205), Congresso Brasileiro de Engenharia de Fabricação, 2019, pp. 1-6 (in Portuguese)

16. H. Spies, C. Eckstein, H. Biermann, and A. Franke, Corrosion Behaviour of Stainless Steels After Low Temperature Thermochemical Treatment, Mater. Sci. Eng. Technol., 2010, 41(3), p 133-141

17. F. Pires, C. Picone, G. Totten, and L. Casteletti, Corrosion Behavior of Plasma Nitrided and Nitrocarburised Supermartensitic Stainless Steel, Mater. Res., 2018, 21(3), p 1-8

18. Z. Szklarska-Smialowska, Pitting and Crevice Corrosion, Houston, NACE International, 2005, p 45-162

19. A. Perren, T. Suter, P. Uggowitzer, L. Weber, R. Magdowski, H. Böhni, and M.O. Speidel, Corrosion Resistance of Super Duplex Stainless Steels in Chloride Ion Containing Environments: Investigations by Means of a New Microelectrochemical Method I. Precipitation-Free States, Corros. Sci., 2011, 43, p 707-726

20. B. Deng, Y. Jiang, J. Gong, C. Zhong, J. Gao, and J. Li, Critical Pitting and Repassivation Temperatures for Duplex Stainless Steel in Chloride Solutions, Electrochim. Acta, 2008, 53, p 5220-5225

21. E. de Souza, S. Rossitti, C. Fortulan, and J. Domingos, Influence of Ferrite Phase Content on the Electrochemical Properties of Duplex Stainless Steels, Mater. Res., 2017, 20(1), p 21-29

22. N. Laycock, M. Moayed, and C. Newman, Metastable Pitting and the Critical Pitting Temperature, J. Electrochem. Soc., 1998, 145(8), p 2622-2628

23. P. Pistorius and G. Burstein, Metastable Pitting Corrosion of Stainless Steel and the Transition to Stability, Philos. Trans. R. Soc., 1992, 341(1662), p 531-559

24. H. Böhni, Localized Corrosion-Mechanisms and Methods, Mater. Sci. Forum, 1992, 111-112, p 401-414

25. M.H. Moayed and R.C. Newman, Evolution of Current Transients and Morphology of Metastable and Stable Pitting on Stainless Steel Near the Critical Pitting Temperature, Corros. Sci., 2006, 48, p 1004-1018

26. Y. Tang, N. Dai, J. Wu, Y. Jiang, and J. Li, Effect of Surface Roughness on Pitting Corrosion of 2205 Duplex Stainless Steel Investigated by Electrochemical Noise Measurements, Materials, 2019, 12(738), p 120

27. L.F. Garfias-Mesias and J.M. Sykes, Metastable Pitting in $14 \mathrm{Cr}$ Duplex Stainless Steel, Corros. Sci., 1999, 41(5), p 959-987

28. F. Helmli, K. Potsch, and C. Repitsch, Choosing the appropriate parameter, Characterisation of Areal Surface Texture, R. Leach, Ed., Springer, Berlin, 2013, p 155-166

29. D. Marton and J. Fine, On the Development of Increasing Surface Roughness During Ion Sputtering, Thin Solid Films, 1987, 151(3), p 433-439

30. Standard Practice for Calculation of Corrosion Rates and Related Information from Electrochemical Measurements, ASTM G102 - 89 (American Society for Testing Materials International, 2015), pp. 1-7

31. S. Esmailzadeh, M. Aliofkhazraei, and H. Sarlak, Interpretation of Cyclic Potentiodynamic Polarization Test Results for Study of Corrosion Behavior of Metals: A Review, Prot. Metals Phys. Chem. Surf., 2018, 54(1), p 976-989

32. D.W. Shoesmith, Kinetics of aqueous corrosion, Corrosion: Fundamentals, Testing, and Protection, Vol 13A, S.D. Cramer and B.S. Covino, Ed., ASM Handbook, ASM International, Novelty, 2003, p $42-51$

33. L. Weber and P. Uggowitzer, Partitioning of Chromium and Molybdenum in Super Duplex Stainless Steels with Respect to Nitrogen and Nickel Content, Mater. Sci. Eng. A, 1998, 242(1-2), p 222-229

Publisher's Note Springer Nature remains neutral with regard to jurisdictional claims in published maps and institutional affiliations. 